\title{
Phytoprotection
}

\section{Ophiostoma ulmi DNA naturally introgressed into an isolate of Ophiostoma novo-ulmi is clustered around pathogenicity and mating type loci \\ Détection d'ADN d'Ophiostoma ulmi introgressé naturellement dans les régions entourant les loci contrôlant la pathogénie et le type sexuel chez 0 . novo-ulmi}

\author{
Abdelali Et-Touil, Mathieu Dusabenyagasani, Guillaume F. Bouvet, Clive M. \\ Brasier et Louis Bernier
}

Volume 99, numéro 1, 2019

URI : https://id.erudit.org/iderudit/1059303ar

DOI : https://doi.org/10.7202/1059303ar

Aller au sommaire du numéro

Éditeur(s)

Société de protection des plantes du Québec (SPPQ)

ISSN

1710-1603 (numérique)

Découvrir la revue

Citer cet article

Et-Touil, A., Dusabenyagasani, M., Bouvet, G. F., Brasier, C. M. \& Bernier, L. (2019). Ophiostoma ulmi DNA naturally introgressed into an isolate of Ophiostoma novo-ulmi is clustered around pathogenicity and mating type loci. Phytoprotection, 99(1), 1-11. https://doi.org/10.7202/1059303ar

\section{Résumé de l'article}

Les champignons pathogènes envahissants Ophiostoma ulmi et $O$. novo-ulmi ont causé deux pandémies successives de maladie hollandaise de l'orme depuis le début du $20^{\mathrm{e}}$ siècle. On a mesuré la croissance et procédé à des analyses moléculaires chez l'isolat $O$. novo-ulmi AST27, modérément agressif et chez lequel le gène de pathogénie Pat1-m est introgressé; chez l’isolat $O$. novo-ulmi H327; chez les isolats $O$. ulmi Q412T et W9; ainsi que chez les descendants de croisements dirigés entre les isolats H327 et AST27. Les analyses génétiques indiquent que les loci Pat1 et Mat1 (type sexuel) sont situés sur des groupes de liaison différents qui correspondent respectivement aux chromosomes 1 et 2 . Les différences moléculaires entre les génomes nucléaires des souches $\mathrm{H} 327$ et AST27 se retrouvent majoritairement dans le voisinage de Pat1 et de Mat1. De plus, deux loci présumés de caractères quantitatifs, $M g r 1$ et $M g r 2$, qui influencent la croissance mycélienne à $21^{\circ} \mathrm{C}$ et à $28^{\circ} \mathrm{C}$ (températures optimales pour $O$. novo-ulmi et $O$. ulmi) sont liés respectivement à Mat1 et à Pat1.
Tous droits réservés @ La société de protection des plantes du Québec, 2019
Ce document est protégé par la loi sur le droit d'auteur. L'utilisation des services d'Érudit (y compris la reproduction) est assujettie à sa politique d'utilisation que vous pouvez consulter en ligne. 


\title{
Ophiostoma ulmi DNA naturally introgressed into an isolate of Ophiostoma novo-ulmi is clustered around pathogenicity and mating type loci
}

\author{
Abdelali Et-Touil ${ }^{1}$, Mathieu Dusabenyagasani², Guillaume F. Bouvet ${ }^{3}$, Clive M. Brasier ${ }^{4}$, \\ Louis Bernier ${ }^{1 \bowtie}$
}

Received 2018-07-13; accepted 2018-11-20

\section{PHYTOPROTECTION 99 : 1-11}

The invasive fungal pathogens Ophiostoma $u / m i$ and $O$. novo-ulmi have caused two successive pandemics of Dutch elm disease since the beginning of the $20^{\text {th }}$ century. In nature, the highly aggressive $O$. novo-ulmi may hybridize with the less aggressive $O$. ulmi. Growth rate and molecular analyses were conducted on an unusual, moderately aggressive $O$. novo-ulmi isolate, AST27, carrying an introgressed pathogenicity gene, Pat1- $m$; on highly aggressive $O$. novo-ulmi isolate $\mathrm{H} 327$; on $\mathrm{O}$. UImi isolates Q412T and W9; and on progeny from laboratory crosses between $\mathrm{H} 327$ and AST27. Genetic analysis indicated that the Pat1 and Mat1 (mating type) loci were in different linkage groups corresponding to $\mathrm{O}$. novo-ulmi $\mathrm{H} 327$ chromosomes 1 and 2, respectively. Most of the molecular differences between the nuclear genomes of H327 and AST27 occurred in the vicinity of Pat1 and Mat1. In addition, two putative quantitative trait loci, Mgr1 and Mgr2, which influence mycelial growth rate at $21^{\circ} \mathrm{C}$ and $28^{\circ} \mathrm{C}$, the optima for 0 . novo-ulmi and $O$. ulmi, were linked to Mat1 and Pat1, respectively.

Keywords: Ophiostoma ulmi, Ophiostoma novo-ulmi, Dutch elm disease, introgression.

[Détection d'ADN d'Ophiostoma ulmi introgressé naturellement dans les régions entourant les loci contrôlant la pathogénie et le type sexuel chez 0 . novo-ulmi]

Les champignons pathogènes envahissants Ophiostoma ulmi et $O$. novo-ulmi ont causé deux pandémies successives de maladie hollandaise de l'orme depuis le début du $20^{\mathrm{e}}$ siècle. On a mesuré la croissance et procédé à des analyses moléculaires chez l'isolat $O$. novo-ulmi AST27, modérément agressif et chez lequel le gène de pathogénie Pat1-m est introgressé; chez l'isolat $O$. novo-ulmi H327; chez les isolats $O$. ulmi Q412T et W9; ainsi que chez les descendants de croisements dirigés entre les isolats H327 et AST27. Les analyses génétiques indiquent que les loci Pat1 et Mat1 (type sexuel) sont situés sur des groupes de liaison différents qui correspondent respectivement aux chromosomes 1 et 2 . Les différences moléculaires entre les génomes nucléaires des souches H327 et AST27 se retrouvent majoritairement dans le voisinage de Pat1 et de Mat1. De plus, deux loci présumés de caractères quantitatifs, Mgr1 et Mgr2, qui influencent la croissance mycélienne à $21^{\circ} \mathrm{C}$ et à $28^{\circ} \mathrm{C}$ (températures optimales pour $\mathrm{O}$. novo-ulmi et $\mathrm{O}$. ulmi) sont liés respectivement à Mat1 et à Pat1.

Mots clés : Ophiostoma ulmi, Ophiostoma novo-ulmi, maladie hollandaise de l'orme, introgression.

1. Centre d'étude de la forêt (CEF), Faculté de foresterie, de géographie et de géomatique, Pavillon Charles-Eugène-Marchand, Université Laval, Québec, QC, Canada G1V 0A6; corresponding author e-mail: Louis.bernier@sbf.ulaval.ca.

2. Canadian Grain Commission, Winnipeg, MB, Canada R3C $3 G 8$.

3. Centre de Recherche Clinique et Évaluative en Oncologie, Québec, QC, Canada G1R 3S1.

4. Forest Research, Farnham, Surrey GU10 4LH, UK. 


\section{INTRODUCTION}

The invasive ascomycete fungus Ophiostoma novo-ulmi Brasier is a highly aggressive vascular wilt pathogen of elms and the principal agent of Dutch elm disease today. Over the past 50 years, it has progressively replaced the less aggressive Ophiostoma ulmi (Buism.) Nannf., which was responsible for the first pandemic of Dutch elm disease across Europe, central Asia and North America in the early 1900s (Brasier 1990). Ophiostoma ulmi and O. novo-ulmi differ in many behavioural and morphological properties. For example, they differ in their growth-temperature optima of $\mathrm{ca} 22^{\circ} \mathrm{C}$ and $28^{\circ} \mathrm{C}$ respectively and in their perithecial dimensions; $O$. ulmi secretes little or none of the cell surface hydrophobin cerato-ulmin while O. novo-ulmi secretes high levels; and the two species are characteristically non-overlapping in their levels of aggressiveness on elms of moderate resistance (Brasier 1991). They also differ extensively in their molecular architecture and are phylogenetically distinct and probably anciently divergent (Pipe et al. 1995). From their temperature relation and other properties, O. ulmi and 0 . novo-ulmi are believed to be adapted to tropical and temperate conditions in their respective centres of origin (Brasier and Mehrotra 1995).

Both species are outcrossing with two mating types, designated MAT-1 and MAT-2, controlled by alleles at a single Mat locus located on chromosome 2 of the 0 . novoulmi H327 genome (Comeau et al. 2015). They are also strongly but not totally reproductively isolated at the preand postzygotic levels (Brasier 1986b, 1991). Detailed analysis of natural populations in O. ulmi/ O. novo-ulmi overlap zones has revealed the occurrence of rare and transient 0 . ulmi $\times$ O. novo-ulmi interspecific hybrids with distinct phenotypes and reduced growth and parasitic fitness (Brasier etal. 1995, 1998; Pipe etal. 2000). An unusual, only moderately pathogenic isolate of $O$. novoulmi, AST27 (Brasier 1986a, 1987), collected in Iran at a location where 0 . novo-ulmi had recently replaced 0 . ulmi (Brasier and Afsharpour 1979), was later shown to be an introgressant harbouring some 0 . ulmi-specific alleles (Bates et al. 1993; Et-Touil et al. 1999). These included Pat1-m, a putative 0 . ulmi pathogenicity allele conferring the moderately aggressive phenotype in AST27 (Et-Touil et al. 1999, 2005), and the OPHIO2-int. DNA transposon (Bouvet et al. 2008). Analysis of population samples collected in Portugal and Poland during the 1980s, when O. novo-ulmi was in the process of displacing 0 . ulmi, revealed other interspecific hybrids, including individuals with intermediate aggressiveness and a distinctive growth response to temperature (Brasier et al. 1998).

These hybrids and introgressants are known to have a major role in the continuing evolution of O. novo-ulmi (reviewed in Brasier et al. 2004). They also provide an opportunity to identify genes associated with fitness. Thus, previous genetic analysis of introgressant isolate AST27 allowed the identification of the Pat1 pathogenicity locus (Et-Touil et al. 1999). Matching alleles for moderate (Pat1$m$ ) and high (Pat1- $h$ ) aggressiveness were identified in AST27 and in normal and highly aggressive O. novo-ulmi isolate H327 respectively, whereas molecular studies with restriction fragment length polymorphisms (RFLPs; Bates etal. 1993) and random amplified polymorphic DNAs (RAPDs; Et-Touil et al. 1999) confirmed that a portion of the AST27 nuclear genome comprised $O$. ulmi-specific sequences. Some, but not all, of the latter were found to be linked to Pat1 (Et-Touil et al. 1999).
In these previous studies, lower aggressiveness towards moderately resistant elms was the only phenotypic trait found to distinguish introgressant AST27 from other isolates of O. novo-ulmi (Brasier 1986a). However, the evidence for O. ulmi-like DNA sequences at various locations in the AST27 genome led us to investigate whether this introgressant isolate expressed other 0 . ulmi-like behavioural traits that might contribute to fitness. In the present study, mycelial growth rates at different temperatures, yeast phase development and cerato-ulmin production levels were quantified in progeny sets from controlled sexual crosses involving AST27 and in wild type isolates of 0 . novoulmi and O. ulmi. Molecular polymorphisms among the isolates were then investigated by polymerase chain reaction (PCR) using specific amplification of coding loci and random amplification of anonymous loci and possible associations between the various characters and isolates analyzed.

\section{MATERIALS AND METHODS}

\section{Isolates and culture media}

The following isolates, described by Et-Touil et al. (1999), were analyzed: highly aggressive $O$. novo-ulmi subsp. novoulmi isolate H327 (Pat1- $h$, MAT-1); moderately aggressive O. novo-ulmi subsp. novo-ulmi introgressant isolate AST27 (Pat1-m, MAT-2); $40 \mathrm{~F}_{1}$ progeny from the cross $\mathrm{H} 327 \mathrm{x}$ AST27; and 50 progeny from the backcross $\mathrm{H} 327 \times \mathrm{A} 2 \mathrm{P} 30$ (Pat1-m, MAT-2). An additional set of $93 \mathrm{~F}_{1}$ progeny was recovered from the cross H327 x AST27. Ophiostoma novoulmi subsp. novo-ulmi isolates AST20 (MAT-1) and CKT11 (MAT-2), O. novo-ulmi subsp. americana isolates FG245 (MAT-1), W2 (MAT-2), MH75 (MAT-2) and CESS16K (MAT2), and O. ulmi isolates Q412T (MAT-1), R21 (MAT-1) and W9 (MAT-2) were also used in some tests. Isolates were routinely grown on solid complete medium (CM) with $2.0 \mathrm{~g} \mathrm{~L}^{-1}$ ammonium sulfate as nitrogen source (Bernier and Hubbes 1990a). Genetic crosses were carried out on elm sapwood agar (Brasier 1981) supplemented with linoleic acid at $6 \mathrm{ml} / \mathrm{L}$ (Bernier and Hubbes 1990a, 1990b). The mating type of progeny strains was determined by crossing each individual with strains H327 and AST27. For long-term storage, aliquots of yeastlike cells grown in liquid CM with L-proline (1.15 $\left.\mathrm{g} \mathrm{L}^{-1}\right)$ as nitrogen source (Bernier and Hubbes 1990a) were mixed with glycerol (to a final concentration of $15 \%$ ) and stored at $-80^{\circ} \mathrm{C}$ (Bernier 1993). Modified $2 \%$ Oxoid (Nepean, ON, Canada) malt extract agar (MEA) was prepared as described in Brasier (1981).

\section{Growth measurements}

Mycelial growth rate on solid medium was measured according to Brasier (1981). Each isolate was inoculated centrally on two sets of MEA plates and incubated in the dark at $21^{\circ} \mathrm{C}$ and $28^{\circ} \mathrm{C}$ (Brasier et al. 1981). After $2 \mathrm{~d}$ (T1) and $7 \mathrm{~d}$ (T2), the diameter (D) of each colony was measured. The mean radial growth rate of each isolate was calculated from three replicates using the equation described by Brasier and Webber (1987): $\mathrm{D}_{2}-\mathrm{D}_{1} / 2\left(\mathrm{~T}_{2}-\mathrm{T}_{1}\right)=$ Radial growth rate per day.

Growth curves were established for yeastlike cell cultures in liquid CM using the method of Bernier and Hubbes (1990a). One-week-old cultures in liquid CM were filtered through eight layers of cheesecloth to remove clumps of cells and mycelia and centrifuged at $4100 \times \mathrm{g}$ for $5 \mathrm{~min}$. The pellet was resuspended in sterile distilled water 
at $1 \times 10^{6}$ cells $\mathrm{mL}^{-1}$. A $500-\mu \mathrm{L}$ aliquot was added to $50 \mathrm{~mL}$ of medium in a $125-\mathrm{mL}^{2}$ Erlenmeyer flask and incubated on a rotary shaker $\left(120 \mathrm{rev} \mathrm{min}^{-1}\right)$ at $25^{\circ} \mathrm{C}$ in the dark. The cell concentration was quantified with a haemocytometer from three replicates and monitored over $8 \mathrm{~d}$.

\section{Cerato-ulmin measurement}

Cerato-ulmin production levels in 1-wk-old culture filtrates of O. novo-ulmi H327, O. ulmi W9 and Q412T, introgressant AST27, F1 progeny A2P5 (Pat1-h, MAT-2) and A2P30 (Pat1-m, MAT-2), and backcross progeny A3P48 (Pat1-h, MAT-2) and A3P11 (Pat1-m, MAT-1), grown in liquid shake culture at $25^{\circ} \mathrm{C}$ in $\mathrm{CM}$, were determined by the turbidity method described by Takai and Richards (1978) and expressed by the cerato-ulmin production index (CPI). The CPI of each isolate was measured as $100 x$ the optical density at $400 \mathrm{~nm}$ from three replicates.

\section{DNA extraction and amplification}

Total genomic DNA was extracted from yeastlike cells grown in liquid CM, according to the procedure of Zolan and Pukkila (1986). DNA was amplified by the polymerase chain reaction (PCR) using RAPD primers (Operon Technologies, Alameda, CA, USA) as described by Et-Touil et al. (1999), as well as primers designed for the specific amplification of coding sequences (Dewar and Bernier 1995; Dusabenyagasani et al. 2000). Bulked segregant analysis (Michelmore et al. 1991) was used to find RAPD markers linked to the matingtype locus. Two bulked DNA samples were prepared from 15 MAT-1 strains (A2P2, A2P3, A2P4, A2P10, A2P11, A2P16, A2P19, A2P20, A2P21, A2P22, A2P25, A2P26, A2P33, A2P35, $\mathrm{A} 2 \mathrm{P} 40$ ) and 15 MAT-2 strains (A2P1, A2P5, A2P6, A2P7, A2P8, A2P9, A2P12, A2P13, A2P14, A2P15, A2P18, A2P23, $A 2 P 29, A 2 P 31, A 2 P 34)$ from the original set of $40 F_{1}$ progeny from the H327 x AST27 cross (Et-Touil et al. 1999). The bulked DNA and parent DNA were screened for differences using 80 RAPD primers as described by Et-Touil et al. (1999). RAPD amplicons were electrophoresed in $1 \%$ agarose and $0.5 \%$ Synergel (Diversified Biotechologies, Boston, MA, USA) gels in $0.09 \mathrm{M}$ Tris-phosphate and $0.002 \mathrm{M}$ EDTA, and visualized by ethidium bromide fluorescence. Gel electrophoresis, alone or in combination with RFLP or single strand conformation polymorphism (SSCP) analysis (Orita et al. 1989) was used to detect polymorphisms in PCR-amplified coding sequences located on six of the eight chromosomes (chr) found in O. novo-ulmi H327 (Comeau et al. 2015): 60S ribosomal protein L34-B and hypothetical eukaryotic translation initiation factor 6 (chr 1); $\beta$-tubulin, mitochondrial ATPase inhibitor, 60S ribosomal protein $\mathrm{L} 35$ and elongation factor 1- $\alpha$ (chr 2); 60S ribosomal protein L30, cytochrome C oxidase chain VIlc-like protein, histidyl-tRNA mitochondrial, cerato-ulmin and nuclear ribosomal rRNA (chr 3); O-glycosyl hydrolase (chr 4); probable eukaryotic translation initiation factor 2- $\beta$, BRCT-containing protein 1 and serine proteinaselike protein (chr 6); actin (chr 8); (Genbank accession numbers AF378547 to AF378553, and AF378555 to AF37867). In addition, Ins-OPHIO2-AST27-L and R primers were used to amplify AST27-specific DNA transposon OPHIO2-int. (Bouvet et al. 2008) in the H327 x AST27 F1 progeny.

\section{Statistical analysis of growth rate and linkage data}

Mycelial growth rate data for the two sets of H327 x AST27 $F_{1}$ progeny, and the $H 327 \times A 2 P 30$ backcross were subjected to ANOVA followed by a Duncan's multiple comparison test. The relationships between mycelial growth rate, pathogenicity, mating-type, and molecular markers were analyzed by carrying out two-tailed Student's $t$ tests. These statistical analyses were performed with SAS version 6.1 software package (SAS Institute Inc., Cary, NC, USA). Recombination among the physiological and molecular markers was studied in the first set of $40 \mathrm{H} 327 \times \mathrm{AST} 27 \mathrm{~F}_{1}$ progeny, using MapMaker Macintosh V2.0 Software (Lander et al. 1987). Linkage among markers segregating in Mendelian fashion was verified with a logarithm of the odds (LOD) score of 4.0 and Theta value of 0.3 . Linkage distances, estimated using the Kosambi function, were first calculated by a two-point analysis, and then by multipoint analysis.

\section{RESULTS}

Forty $\mathrm{H}_{32} 27 \mathrm{x}$ AST27 $\mathrm{F}_{1}$ progeny ( $\mathrm{F}_{1}$ set 1 ) and fifty $\mathrm{H} 327 \mathrm{x}$ A2P30 backcross progeny examined for pathogenicity by EtTouil et al. (1999) during the identification of the Pat1 locus were investigated for mating type, for other phenotypically observable traits, for segregation of putative quantitative trait loci (QTLs), and for additional associated molecular markers. A further $93 \mathrm{~F}_{1}$ progeny from the cross $\mathrm{H} 327 \mathrm{x}$ AST27 ( $F_{1}$ set 2 ) was also examined in many of the tests.

\section{Mating types}

The MAT- 1 and MAT- 2 mating types segregated in Mendelian fashion in H327 x AST27 $F_{1}$ set $1\left(15: 25 ; \chi^{2}=2.500\right)$ but not in set 2 (34:59; $\left.\chi^{2}=6.720, P<0.01\right)$. The two mating types also segregated in Mendelian fashion $\left(22: 25 ; \chi^{2}=0.191\right)$ in the 47 isolates from the $\mathrm{H} 327 \times \mathrm{A} 2 \mathrm{P} 30$ backcross progeny for which mating reactions could be determined.

\section{Mycelial growth rate at $21^{\circ} \mathrm{C}$ and $28^{\circ} \mathrm{C}$}

Growth rate tests of the two $F_{1}$ and one backcross progeny sets were conducted on MEA at $21^{\circ} \mathrm{C}$ and at $28^{\circ} \mathrm{C}$, close to the optima for $O$. novo-ulmi and $O$. ulmi, respectively (Brasier et al. 1981). The data were then analyzed for their relationship to parental growth rates, to mating type and to pathogenicity (Pat1-h or Pat1-m). The pathogenicity data were available only for $F_{1}$ set 1 and for the backcross progeny (Et-Touil et al. 1999). The results are summarized in Tables 1 and 2 and Figs. 1 and 2.

At $21^{\circ} \mathrm{C}$, O. novo-ulmi isolate $\mathrm{H} 327$ grew significantly faster $\left(4.95 \mathrm{~mm} \mathrm{~d}^{-1} ; F=7.70, P<0.001\right)$ than 0 . novo-ulmi introgressant AST27 $\left(4.11 \mathrm{~mm} \mathrm{~d}^{-1}\right)$; and AST27 grew significantly faster than O. ulmi isolates Q412T and W9 (3.25 and $2.95 \mathrm{~mm} \mathrm{~d}^{-1}$, respectively) (Fig. 1A). Both H327 and AST27 therefore show the 0 . novo-ulmi characteristic of a faster growth rate than $O$. ulmi at this temperature. Linear growth rates of both $F_{1}$ progeny sets were continuously distributed (Fig. 1A for set 1 ). For each set, the overall progeny mean did not differ significantly from the H327/AST27 midparent value. In set 1 , the 21 Pat1- $h$ and the 19 Pat1-m siblings exhibited comparable mean mycelial growth rates. The 15 MAT-1 individuals, however, grew significantly $(P<0.01)$ faster than their 25 MAT-2 siblings (Table 1). This behavior was also observed in the $93 \mathrm{~F}_{1}$ progeny set 2 .

At $28^{\circ} \mathrm{C}$, O. novo-ulmi AST27 (3.05 $\left.\mathrm{mm} \mathrm{d}^{-1}\right)$ and O. ulmi Q412T (4.21 $\left.\mathrm{mm} \mathrm{d}^{-1}\right)$ grew significantly faster than $O$. novoulmi H327 (2.95 $\mathrm{mm} \mathrm{d}^{-1} ; F=6.72, P<0.001$ ). Isolate AST27 also grew significantly faster than $\mathrm{H} 327$ at $28^{\circ} \mathrm{C}$ in two retests (4.98 vs 4.30 and 5.12 vs $4.17 \mathrm{~mm} \mathrm{~d}^{-1}$, respectively) i.e. it exhibited a more 0 . ulmi-like property. In both $\mathrm{F}_{1}$ progeny sets, the distribution of growth rates was again continuous (Fig. 1B for set 1). The overall means of the two 
Table 1. Relationship between mycelial growth rate, mating type and pathogenicity in O. novo-ulmi H327 x AST27 progeny sets

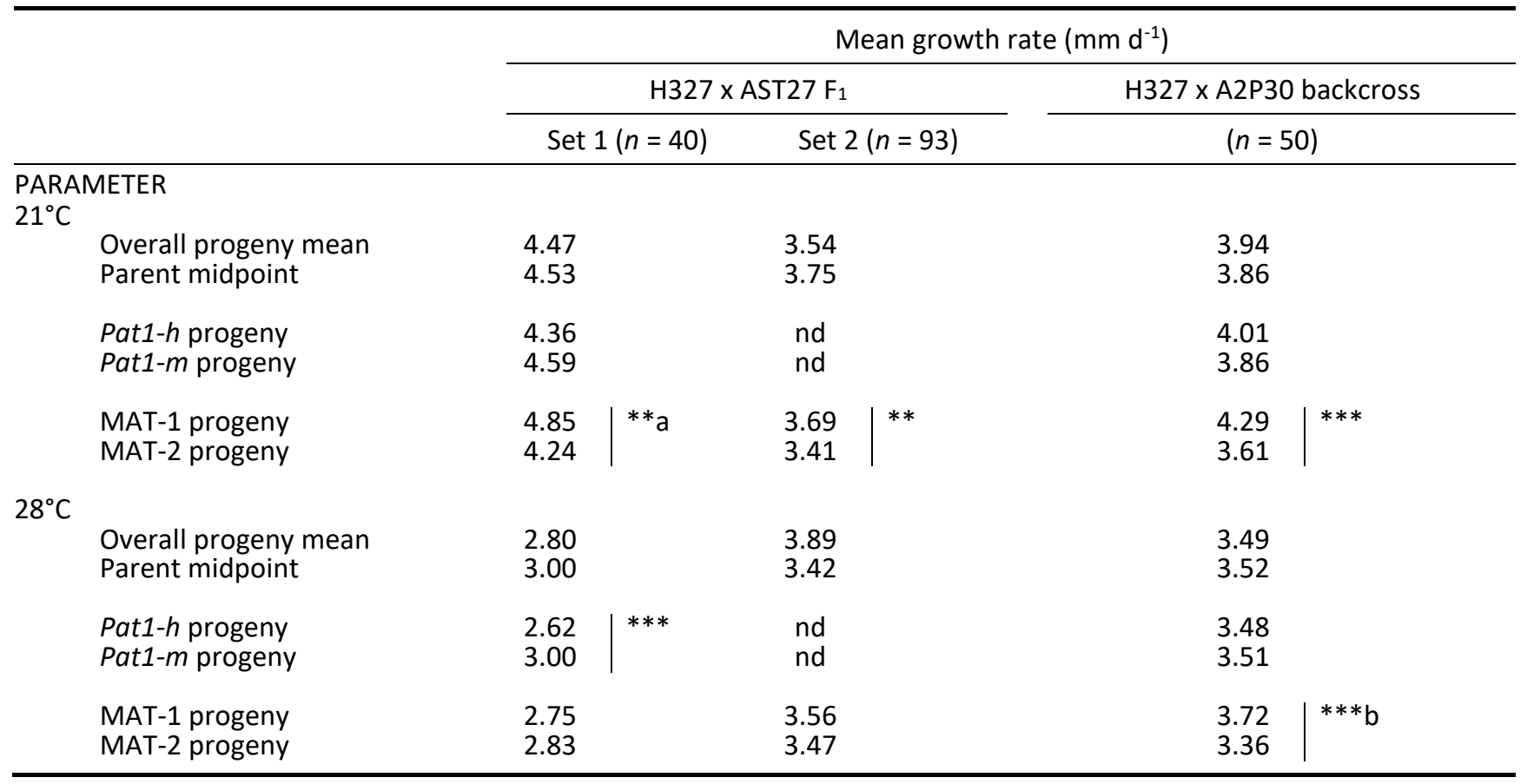

a Vertical bar, significant difference between the two values: ${ }^{*}, P<0.05 ; * *, P<0.01 ; * * *, P<0.001$.

b In two retests, no significant differences in growth rate at $28^{\circ} \mathrm{C}$ were observed between MAT-1 and MAT-2 backcross progeny.

progeny sets were again similar to their respective $\mathrm{H} 327$ and AST27 midparent values. With set 1 , however, the Pat1-m progeny grew at a significantly higher rate than Pat1-h progeny $(P<0.001)$, whereas the MAT-1 and MAT-2 progeny of both $\mathrm{F}_{1}$ sets exhibited similar growth rates (Table 1 ).

The $50 \mathrm{H} 327 \times \mathrm{A} 2 \mathrm{P} 30$ backcross progeny also exhibited continuous distributions for growth rates at $21^{\circ} \mathrm{C}$ and $28^{\circ} \mathrm{C}$ (Fig. 2). The 24 Pat1- $m$ individuals and 26 Pat1- $h$ individuals displayed a similar growth rate at both $21^{\circ} \mathrm{C}$ and $28^{\circ} \mathrm{C}$ (Table 1). The 22 MAT-1 progeny grew significantly faster, on average, than the 25 MAT- 2 progeny at $21^{\circ} \mathrm{C}(P<0.001$; Table 1).

Overall, therefore, these data suggested that genetic factors controlling growth rate were segregating among the H327 x AST27 progeny and that some of these factors might be associated with the Mat1 or Pat1 loci.

Table 2. Physiological characteristics of O. novo-ulmi (H327), introgressant (AST27), progeny from H327 x AST27 crosses (A2P5, A2P30), backcross progeny from H327 x A2P30 crosses (A3P11, A3P48), and O. ulmi (W9 and Q412T)

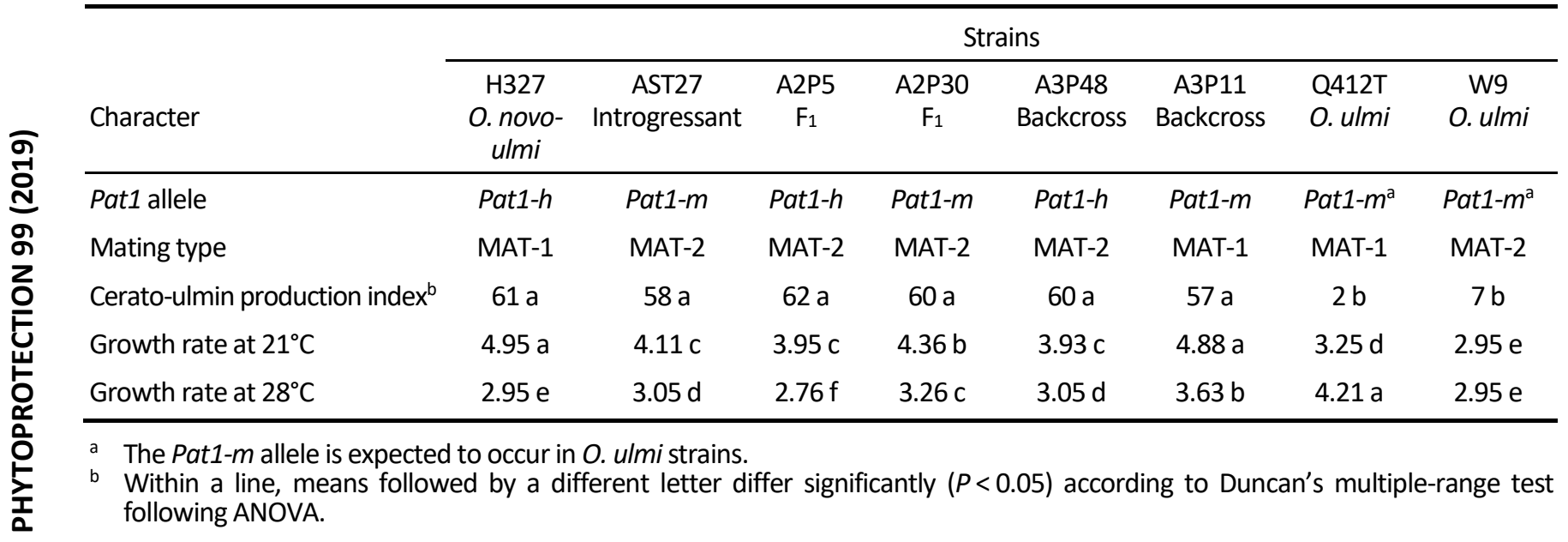


A

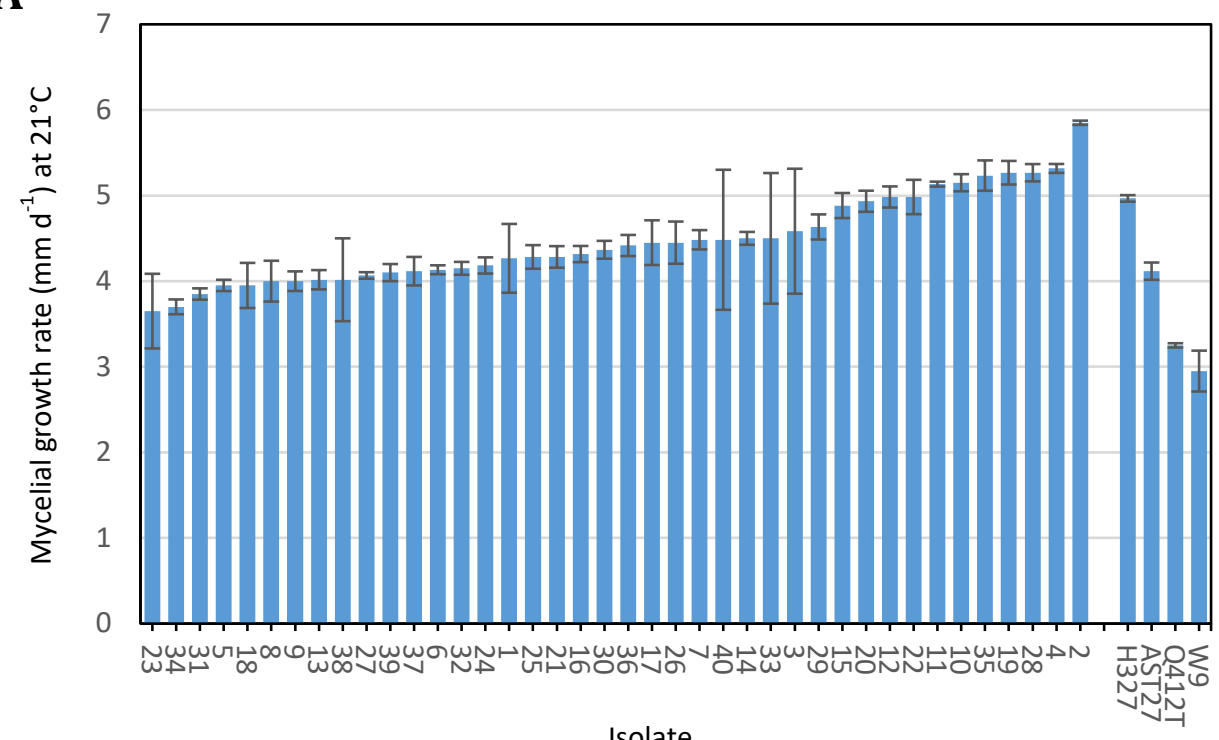

B

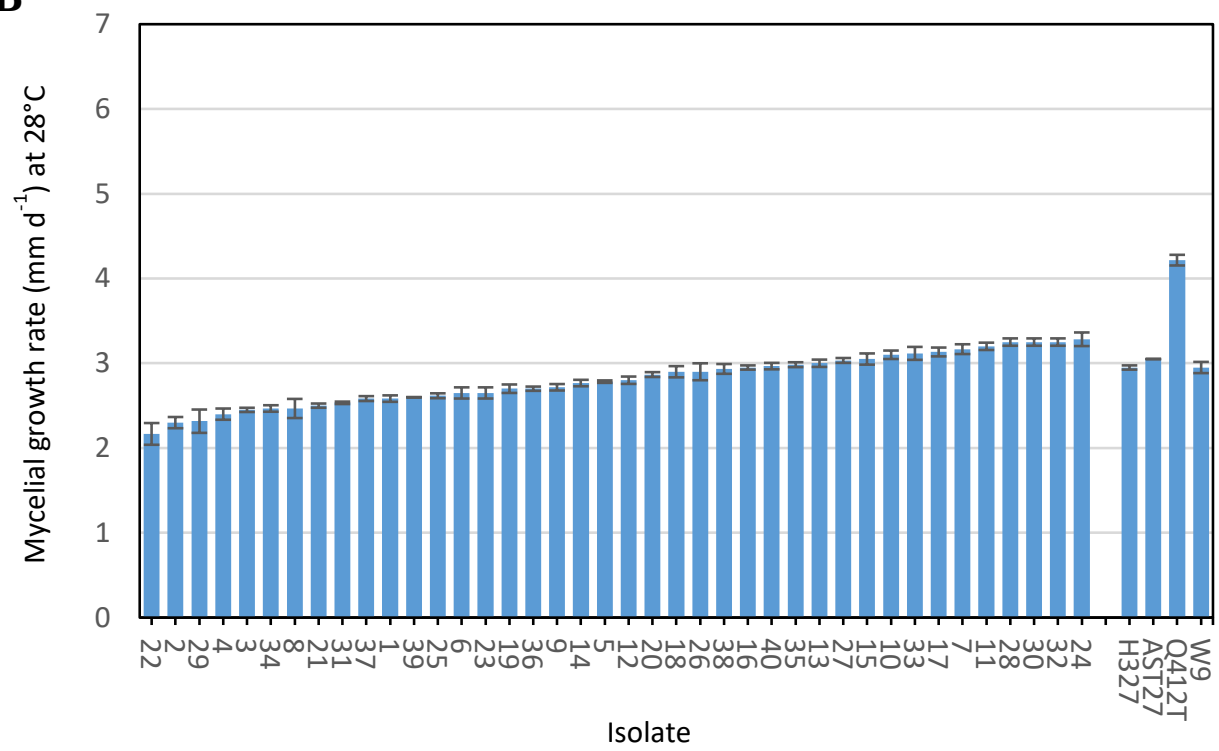

Figure 1. Mycelial growth rate distribution at $21^{\circ} \mathrm{C}(\mathrm{A})$ and $28^{\circ} \mathrm{C}(\mathrm{B})$ of the $40 \mathrm{~F}_{1}$ set 1 progeny from a cross between the highly aggressive Ophiostoma novo-ulmi $\mathrm{H} 327$ and the moderately aggressive O. novo-ulmi introgressant AST27. Isolates W9 and Q412T belong to 0 . ulmi. All measurements are means of three replicates. Vertical bars represent standard error. A continuous distribution at $21^{\circ} \mathrm{C}$ and $28^{\circ} \mathrm{C}$ was also observed for a second set of $93 \mathrm{~F}_{1}$ progeny (data not shown).

\section{Yeast growth and cerato-ulmin production}

In liquid shake cultures, the yeast phases of 0 . novo-ulmi isolates H327 and AST27 grown in CM displayed nearly similar growth kinetics at $25^{\circ} \mathrm{C}$. The only notable difference was observed after $96 \mathrm{~h}$ of incubation when cell concentrations of AST27 were lower than those recorded for H327 (Fig. 3). Both isolates grew more rapidly than 0 . ulmi Q412T and W9 after ca $80 \mathrm{~h}$ (Fig. 3). Similarly, H327 and AST27, two selected $\mathrm{F}_{1}$ progeny isolates (A2P5 and $\mathrm{A} 2 \mathrm{P} 30$ ) and two selected backcross isolates (A3P48 and A3P11) produced comparably high levels of cerato-ulmin, whereas isolates Q412T and W9 produced very small amounts of cerato-ulmin (Table 2) typical of O. ulmi (Scala et al. 1997; Takai 1980). Since yeast growth kinetics and cerato-ulmin production were similar for parent isolates, these traits were not studied further in progeny isolates.

\section{Molecular polymorphisms}

Sixteen coding sequences which had been previously assigned to the six O.novo-ulmi chromosomes distinguishable by pulsed-field gel electrophoresis (Dewar and Bernier 1995; Dewar et al. 1997; Dusabenyagasani et al. unpubl.) were amplified in H327 and AST27 and subjected to RFLP or SSCP analysis to determine whether they corresponded to $O$. ulmi or 0 . novo-ulmi specific alleles. Results indicated that introgressant AST27 harboured no O. ulmi-specific alleles among 
the 16 coding loci analyzed. Following sequencing and assembly of the $\mathrm{O}$. novo-ulmi $\mathrm{H} 327$ nuclear genome into eight chromosomes (Forgetta et al. 2013) and its subsequent annotation (Comeau et al. 2015), it was found that two chromosomes (chr 5 and 7) were not represented in the set of 16 coding sequences. On the other hand, the OPHIO2-int. DNA transposon (Bouvet et al. 2008) segregated in the progeny (Table 1).

A comparison of RAPD patterns of $\mathrm{H} 327$ and AST27 yielded 26 additional reproducible polymorphisms. These included the 10 RAPD loci linked to Pat1 reported previously (Et-Touil et al. 1999). These loci were assigned to chDNA II (Et-Touil et al. 1999) which corresponds to chromosome 1 of the O. novo-ulmi reference genome (Forgetta et al. 2013; Comeau etal. 2015). Seven RAPD loci were polymorphic between MAT-1 and MAT-2 bulked samples of $F_{1}$ progeny: OPA8500, OPA11 1900, OPA121900, OPJ1600, OPJ61200, OPK12500, and OPK17 1400 . One of these markers, OPA12 1900 , was amplified in parent strain AST27 and in O. ulmi strains but not in parent strain $\mathrm{H} 327$ nor in other O. novo-ulmi strains tested. Recombination analysis of the first set of $40 \mathrm{~F}_{1}$ progeny confirmed that the above markers were all linked to the Mat1 locus, located on O. novo-ulmi H327 chromosome 2 (Comeau et al. 2015), and further indicated that an additional locus, OPJ1680, was also linked to Mat1. These eight RAPD markers and the Mat1 locus segregated independently from Pat1 and the 11 molecular markers linked to it. Among the remaining eight RAPD polymorphisms, three loci (OPC2635, OPC2760 and OPK18760) cosegregated only with each other and were assigned to linkage group III (O. novo-ulmi H327 chr 8). Locus OPC2 1100 was tentatively assigned to chromosome 3 (Dusabenyagasani et al. unpubl), whereas OPC191900, OPJ1620, OPJ1 2050 and OPK5 1060 could not be assigned to any linkage group or chromosome (Fig. 4).

A

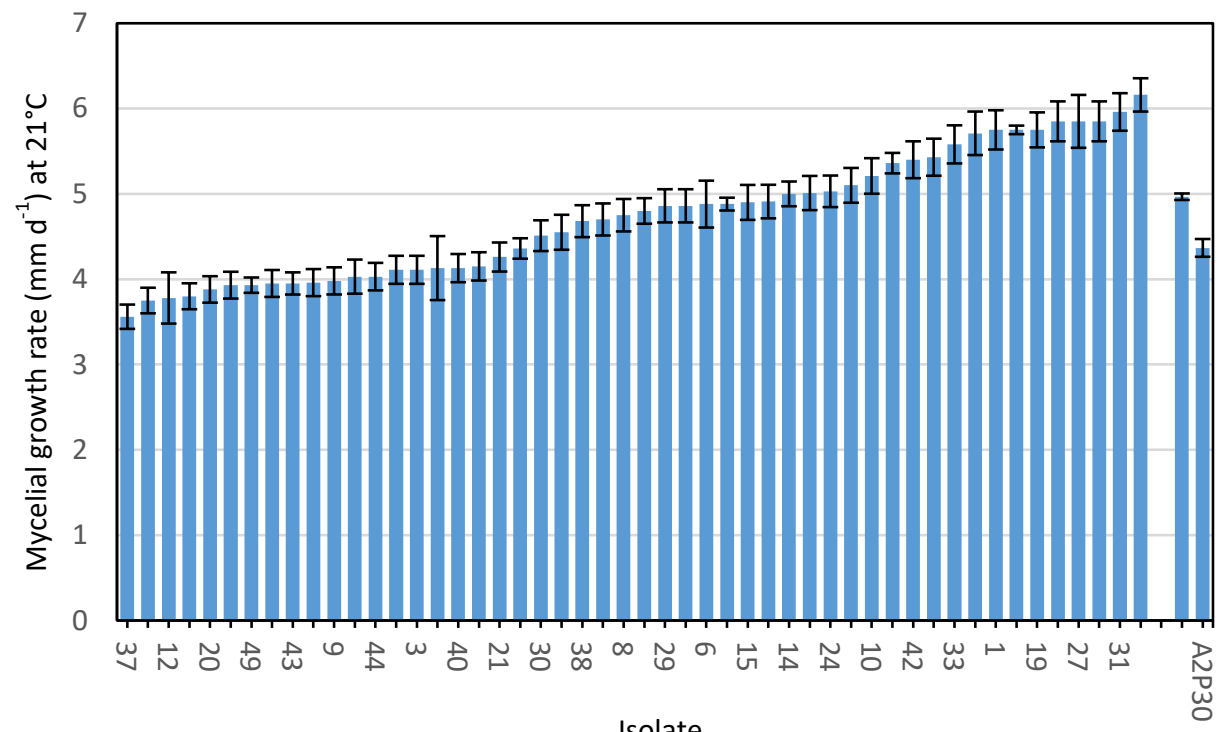

B

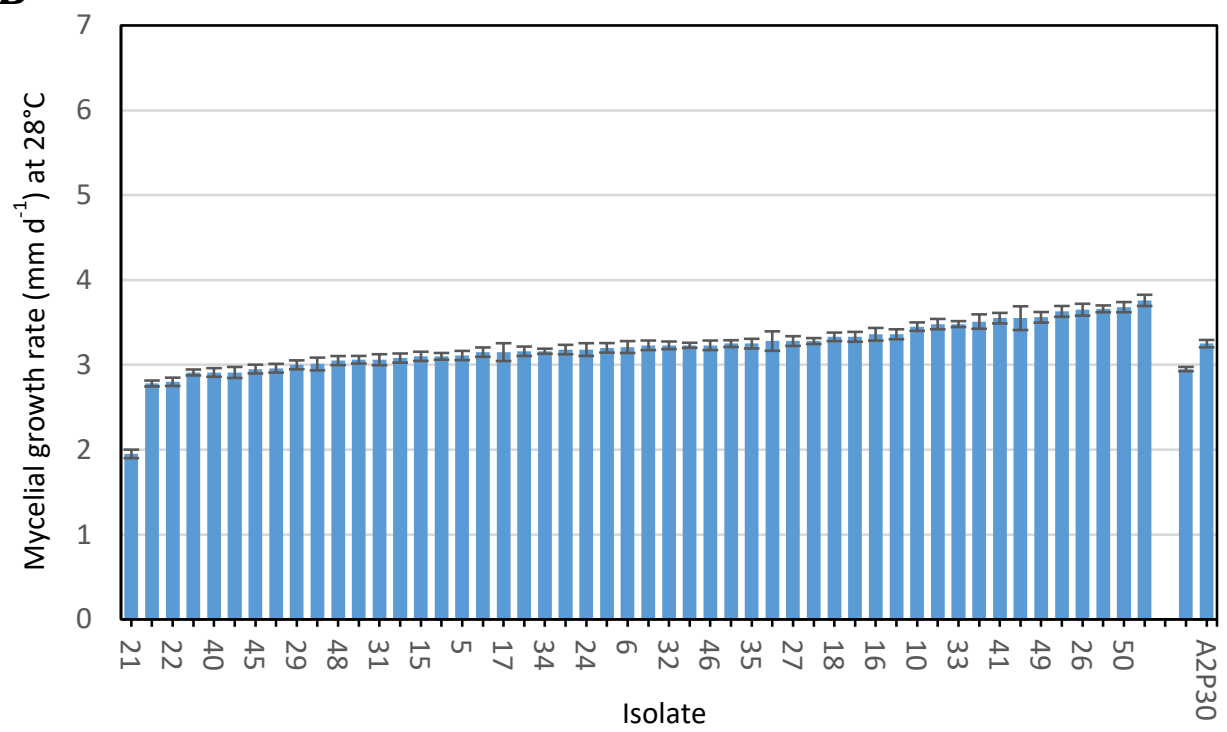

Figure 2. Mycelial growth rate distribution at $21^{\circ} \mathrm{C}(\mathrm{A})$ and $28^{\circ} \mathrm{C}(\mathrm{B})$ of 50 progeny from a backcross between the highly aggressive Ophiostoma novo-ulmi H327 and a moderately aggressive $\mathrm{F}_{1}$ progeny (A2P30). All measurements are means of three replicates. Vertical bars represent standard error. 


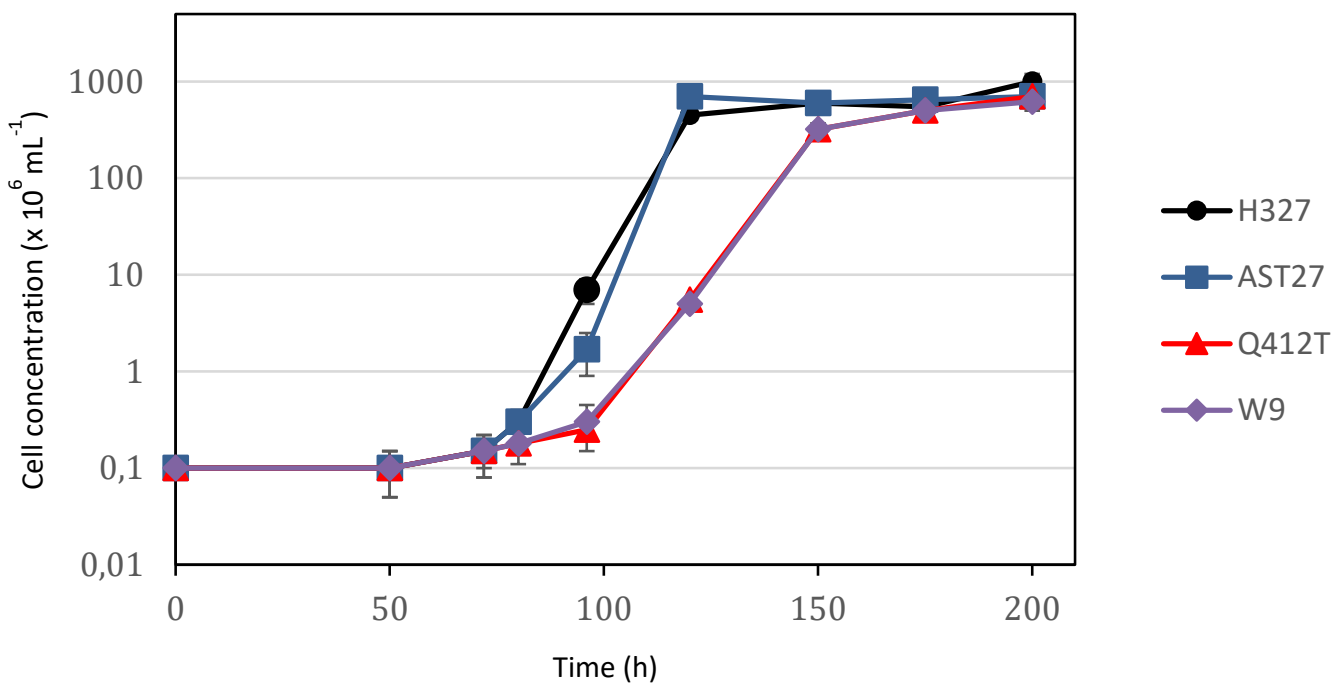

Figure 3. Yeastlike cell growth kinetics of $O$. novo-ulmi (H327), O. novo-ulmi introgressant (AST27) and O. ulmi (Q412T, W9) in liquid complete medium. Triplicate cultures were incubated on a rotary shaker $\left(120 \mathrm{rev} \mathrm{min}^{-1}\right)$ at $25^{\circ} \mathrm{C}$ in the dark. Standard errors are shown only when they exceed the size of the symbol.

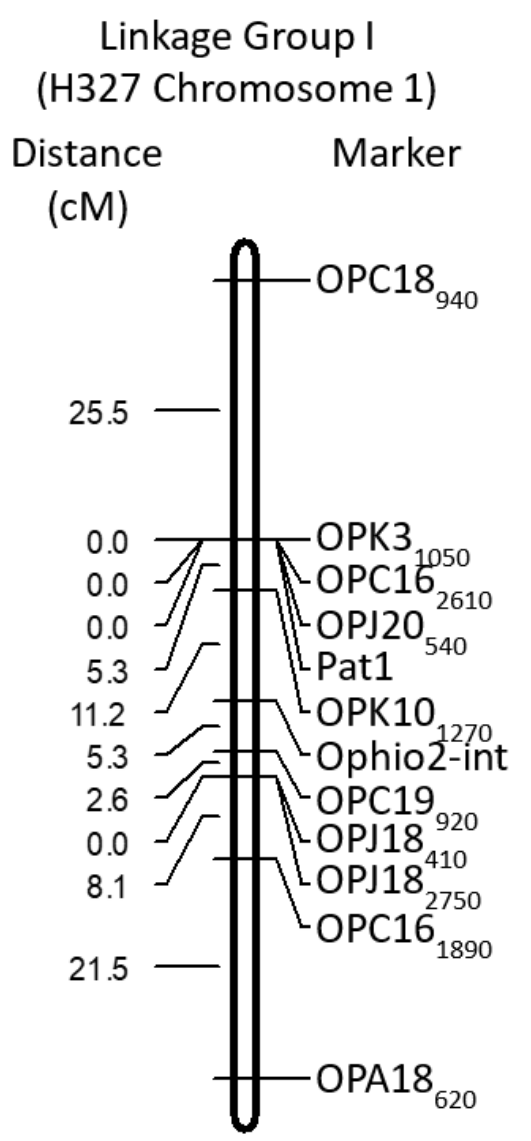
Linkage Group II (H327 Chromosome 2)

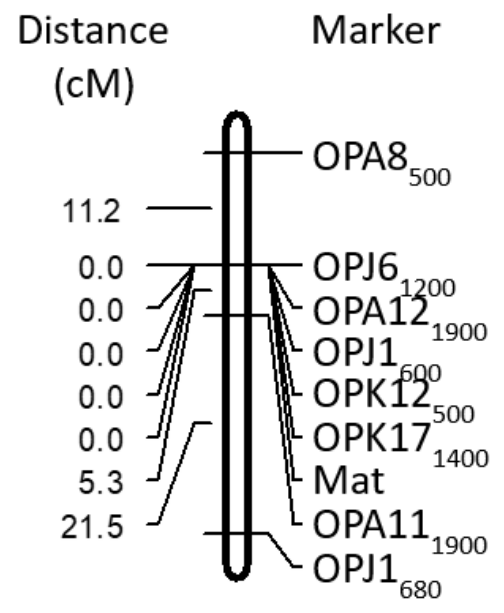

\section{Linkage Group II \\ (H327 Chromosome 8)}

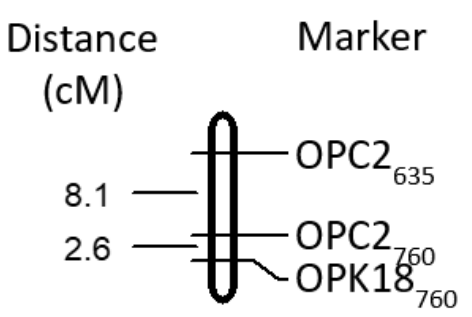

Figure 4. Linkage analysis of coding loci (Pat1 and Mat), transposon OPHIO2-int. and 26 anonymous RAPD loci. The map is based on the analysis of $40 \mathrm{~F}_{1}$ set 1 progeny from the cross between Ophiostoma novo-ulmi H327 (Pat1- $h$, MAT-1) x introgressant AST27 (Pat1-m, MAT-2). Map distances, estimated with the Kosambi function, were calculated by multipoint analysis with a LOD score of 4.0 and theta of 0.3, using MapMaker V2.0 for Macintosh. 


\section{Relationship between RAPD markers and growth rate}

Mycelial growth rates of the $40 \mathrm{~F}_{1}$ set 1 progeny data were compared to their allelic differences at the RAPD loci described above. Allelic differences at all eight RAPD loci linked to Mat1 were associated with significant $(P<0.01)$ differences in mycelial growth rate at $21^{\circ} \mathrm{C}$ (Table 3$)$. None of the polymorphisms at the remaining RAPD loci were associated with the significant differences in mycelial growth rates observed at this temperature (Table 1). The OPHIO2-int. transposon and 10 RAPD polymorphisms linked to Pat1 were associated with significant $(P<0.01)$ differences in mycelial growth rate at $28^{\circ} \mathrm{C}$ (Table 3 ). None of the other RAPD loci investigated showed a significant association with mycelial growth rate at $28^{\circ} \mathrm{C}$.

Table 3. Segregation of parental Pat1 or Mat alleles, molecular markers and mycelial growth rates in the set $1 F_{1}$ progeny from the cross H327 x AST27

\begin{tabular}{|c|c|c|c|c|c|c|}
\hline $\begin{array}{c}\text { Inferred } \\
\text { linkage group }\end{array}$ & Marker & $\begin{array}{c}\text { H327 allele } \\
\text { (Pat1-h or Mat1-1) } \\
\alpha^{\mathrm{a}}\end{array}$ & $\begin{array}{c}\text { AST27 allele } \\
\text { (Pat1-m or Mat1-2) } \\
\beta\end{array}$ & $\chi^{2}$ & $\begin{array}{l}\Delta 21^{\circ} \mathrm{C} \\
(\alpha-\beta)^{\mathrm{b}}\end{array}$ & $\begin{array}{c}\Delta 28^{\circ} \mathrm{C} \\
(\alpha-\beta)\end{array}$ \\
\hline \multicolumn{7}{|l|}{1} \\
\hline & Pat1 & 21 & 19 & 0.100 & -0.23 & $-0.38^{* *}$ \\
\hline & OPA18620 & 16 & 24 & 1.600 & -0.25 & $-0.41 * *$ \\
\hline & OPC16 1890 & 19 & 21 & 0.100 & -0.23 & $-0.38^{* *}$ \\
\hline & OPC16 2610 & 21 & 19 & 0.100 & -0.23 & $-0.38 * *$ \\
\hline & OPC18940 & 15 & 25 & 2.500 & +0.01 & $-0.33^{* *}$ \\
\hline & OPC19920 & 19 & 21 & 0.100 & -0.18 & $-0.46 * *$ \\
\hline & OPJ18410 & 20 & 20 & 0.000 & -0.22 & $-0.45^{* *}$ \\
\hline & OPJ18 2750 & 20 & 20 & 0.000 & -0.22 & $-0.45^{* *}$ \\
\hline & OPJ20540 & 21 & 19 & 0.100 & -0.23 & $-0.38 * *$ \\
\hline & OPK31050 & 21 & 19 & 0.100 & -0.23 & $-0.38 * *$ \\
\hline & OPK10 1270 & 19 & 21 & 0.100 & -0.17 & $-0.40 * *$ \\
\hline & OPHIO2-int. & 16 & 24 & 1.600 & -0.14 & $-0.47^{* *}$ \\
\hline II & Mat & 15 & 25 & 2.500 & $+0.61^{* *}$ & -0.08 \\
\hline & OPA8500 & 19 & 21 & 0.100 & $+0.45^{* *}$ & -0.01 \\
\hline & OPA11 1900 & 17 & 23 & 0.900 & $+0.63 * *$ & -0.08 \\
\hline & OPA12 1900 & 15 & 25 & 2.500 & $+0.61 * *$ & -0.08 \\
\hline & OPJ1600 & 15 & 25 & 2.500 & $+0.61 * *$ & -0.08 \\
\hline & OPJ1 $1_{680}$ & 18 & 22 & 0.400 & $+0.43^{* *}$ & -0.03 \\
\hline & OPJ6 1200 & 15 & 25 & 2.500 & $+0.61^{* *}$ & -0.08 \\
\hline & OPK12500 & 15 & 25 & 2.500 & $+0.61 * *$ & -0.08 \\
\hline & OPK171400 & 15 & 25 & 2.500 & $+0.61 * *$ & -0.08 \\
\hline \multicolumn{7}{|l|}{ III } \\
\hline & OPC2 635 & 23 & 17 & 0.900 & +0.14 & -0.06 \\
\hline & OPC2760 & 21 & 19 & 0.100 & +0.18 & -0.12 \\
\hline & OPK18760 & 23 & 17 & 0.900 & +0.16 & -0.07 \\
\hline \multicolumn{7}{|l|}{ Unlinked } \\
\hline & OPC2 1100 & 25 & 15 & 2.500 & -0.06 & +0.01 \\
\hline & OPC19 1900 & 18 & 22 & 0.400 & +0.03 & +0.15 \\
\hline & OPJ1620 & 15 & 25 & 2.500 & +0.26 & -0.18 \\
\hline & OPJ1 $1_{2050}$ & 14 & 26 & 3.600 & -0.10 & +0.17 \\
\hline & OPK51060 & 20 & 20 & 0.000 & +0.30 & +0.13 \\
\hline
\end{tabular}

a $\alpha$ and $\beta$ represent $\mathrm{H} 327$-type and AST27-type alleles, respectively.

b For any given locus, values are the difference in mean mycelial growth rate $\left(\mathrm{mm} \mathrm{d}^{-1}\right)$ between progeny with the $\mathrm{H} 327$ allele $(\alpha)$ or the AST27 allele $(\beta) .{ }^{*}, P<0.05 ;{ }^{*}, P<0.01$. 


\section{DISCUSSION}

In a previous study, the unusually low aggressiveness of AST27 relative to wild-type O. novo-ulmi isolates (Brasier 1986a) was shown to be due to a single nuclear allele, Pat1-m. Since this allele was also closely linked to two of the five O. ulmi-specific amplicons found in the AST27 genome, it was considered to be introgressed from O. ulmi (Et-Touil et al. 1999). In this study we have used a combination of physiological and molecular tests to identify other traits in AST27 and its derivatives that might be both genetically tractable and associated with interspecific hybridization.

One feature observed in AST27 was that it exhibited distinctive mycelial growth rates at $21^{\circ} \mathrm{C}$ and at $28^{\circ} \mathrm{C}$, close to the optima for growth of O. novo-ulmi and O. ulmi, respectively (Brasier et al. 1981). When incubated at either temperature, isolate AST27 exhibited a growth rate that was intermediate between the rates of 0 . novo-ulmi H327 and O. ulmi Q412T. Two sets of H327 x AST27 $\mathrm{F}_{1}$ progeny, and a backcross population showed a continuous distribution for growth rate at both $21^{\circ} \mathrm{C}$ and $28^{\circ} \mathrm{C}$. This was in marked contrast to the heritability pattern of their pathogenicity phenotypes, which segregated 1:1 for highly vs moderate aggressiveness, consistent with monogenic control (Brasier 1987; Et-Touil et al. 1999). The observed differences in temperature-growth responses of $\mathrm{H} 327$ and AST27 at $21^{\circ} \mathrm{C}$ and $28^{\circ} \mathrm{C}$ were therefore most probably due to multiple genetic differences. The assumption that some of these loci were segregating independently from each other was supported by the fact that some of the fastest growing progeny isolates at $21^{\circ} \mathrm{C}$ were among the slowest growing at $28^{\circ} \mathrm{C}$ and vice versa (Figs. 1 and 2).

Co-analysis of additional markers with the $F_{1}$ set 1 progeny further supported the hypothesis that the growth rate differences between isolates H327 and AST27 were due to allelic differences at several loci. The MAT-1 progeny grew faster than their MAT-2 siblings at $21^{\circ} \mathrm{C}$ and the Pat1$m$ progeny grew faster than the Pat1- $h$ progeny at $28^{\circ} \mathrm{C}$. Similar results were obtained when linkage of molecular markers to Pat1 or Mat was examined (Table 2). Linkage analysis of 29 genetic markers that included Pat1, Mat1, OPHIO2-int. and 26 RAPD polymorphisms (Fig. 4) clearly showed that the Pat1 and Mat1 loci belonged to different linkage groups (I and II, respectively), as expected from markers located on different chromosomes ( 1 and 2 , respectively, according to Comeau et al. 2015).

Among the $F_{1}$ and backcross progeny analyzed, however, some Pat1- $h$ isolates grew significantly faster than both parents at $28^{\circ} \mathrm{C}$. Likewise, some MAT-2 individuals were among the fastest growing isolates at $21^{\circ} \mathrm{C}$. These findings suggest that the Mat1 and Pat1 loci themselves do not directly influence mycelial growth rates at $21^{\circ} \mathrm{C}$ and $28^{\circ} \mathrm{C}$; but are rather linked to two genetic factors or putative quantitative trait loci (QTLs) controlling mycelial growth rate (mgr) that we propose to call Mgr1 and Mgr2, respectively. The precise localization of these putative QTLs is unclear owing to the low number of informative genetic polymorphisms found so far between H327 and AST27 and the small sets of progeny analyzed. Nevertheless, it is evident from the RAPD and growth rate data that both putative mgr QTLs are located in regions of the AST27 nuclear genome that contain many $\mathrm{O}$. ulmi-specific sequences. It therefore appears likely that they are derived from O. ulmi and that introgression of O. ulmi DNA is responsible for the distinctive growth phenotype of AST27 in addition to its reduced aggressiveness (Et-Touil et al. 1999). We found no evidence for mgr QTLs elsewhere in the Ophiostoma genome. This is not surprising since we analyzed progeny derived from only two field isolates (H327 and AST27) and sampled a very small portion of the $c a$. 32-megabase nuclear genome of the Dutch elm disease fungi (Forgetta et al. 2013; Khoshraftar et al; 2013). Nevertheless, our data indicate that a region of chromosome 8 in introgressant AST27 also contains O. ulmispecific RAPD markers. We therefore expect neighbouring genes to be polymorphic between isolates H327 and AST27.

The significant difference in mycelial growth rate between Pat1-m and Pat1- $h \mathrm{~F}_{1}$ progeny at $28^{\circ} \mathrm{C}$ was not observed in the $\mathrm{H} 327 \times \mathrm{A} 2 \mathrm{P} 30$ backcross population. This apparent discrepancy may be explained by the genotype of backcross parent isolate A2P30, which not only carried the Pat1-m and Mat1-2 alleles from AST27 but also H327-type alleles for four of the 26 RAPD loci analyzed, viz. OPJ1680, OPC2 1100, OPC19 1900 and OPK5 1060. H327-type coding genes linked to any of these markers may have interacted with the Mgr1 locus.

The clustering of $O$. ulmi DNA around the Mat1 and Pat1 loci may have adaptive significance. Little is known about the genome reorganization in interspecific hybrids among filamentous fungi, but it is likely that natural selection will have a strong influence on the process (Brasier 1995). It has been shown that as $O$. novo-ulmi has replaced $O$. ulmi across the Northern Hemisphere it has acquired the Mat1-1 allele and vegetative compatibility (Vic) alleles from $O$. ulmi at a high frequency (Paoletti et al. 2006). We have also found that most $O$. ulmi DNA detected in the O. novo-ulmi isolates examined flanked the introgressed Mat1 and Vic loci. Brasier et al (2004) proposed that the most likely mode of introgression of the Mat1 and Vic loci was via sexual hybridization of $O$. novo-ulmi with $O$. ulmi followed by sequential backcrossing of resulting $\mathrm{F}_{1} \mathrm{~S}$ to 0 . novo-ulmi. O. ulmix O. novo-ulmi $F_{1}$ progeny tend to be highly unfit and transient in nature, most being of very low pathogenicity. Backcross genotypes still carrying "unuseful" $O$. ulmi genes, i.e. alleles conferring low fitness on 0 . novo-ulmi, are also probably transient, i.e. eliminated by natural selection. The end result is likely to be selective acquisition and fixation by $O$. novoulmi of "useful" O. ulmi alleles (in this case, alleles at the Mat and Vic loci that confer resistance to fungal viruses) and a clustering of residual neutral O. ulmi DNA around these loci.

Isolate AST27 exhibits higher pathogenic fitness than most 0 . ulmi 0 . novo-ulmi $\mathrm{F}_{1}$ progeny and is also more aggressive to healthy elms than is $O$. ulmi. It was originally isolated from the xylem of a symptomatic elm sapling and was therefore successful in the vascular wilt phase of the pathogen. AST27 shares most of its other properties with O. novo-ulmi. It may therefore be an intermediate or late backcross product in which some phenotypically important O. ulmi genes, including 0 . ulmi genes for lower aggressiveness (Pat1- $m$ ) and faster growth rate at $28^{\circ} \mathrm{C}$ (Mgr2), are still present. In areas with populations of moderately to highly resistant elms, it is likely that AST27 would soon have been eliminated through competition with fitter O. novo-ulmi genotypes. However, in areas where susceptible elms are frequent, an AST27-type introgressant could overcome host resistance (Et-Touil et al. 2005) and be disseminated efficiently by elm bark beetles given its ability to secrete high amounts of cerato-ulmin (Temple et al. 1997). Genetic analysis of progeny from laboratory crosses suggests that such introgressants might contribute additional useful traits to O. novo-ulmi through sexual hybridization. For instance, $\mathrm{H} 327 \times \mathrm{AST} 27 \mathrm{~F}_{1}$ isolate A2P33 and backcross isolates A3P26 and A3P33 grew well at both $21^{\circ} \mathrm{C}$ and $28^{\circ} \mathrm{C}$ (Figs. 1 and 2) and were highly aggressive (Et-Touil et al. 1999). Large scale 
genomic analyses of 0 . novo-ulmi populations in historical O. ulmi/O. novo-ulmi overlap zones are needed to determine whether, apart from O. ulmi Vic and Mat1 loci, O. ulmi loci governing some other adaptive traits have been fixed or simply eliminated by intense post-epidemic selection.

\section{ACKNOWLEDGEMENTS}

This work was supported by grants from the Natural Sciences and Engineering Research Council of Canada (NSERC) to L. Bernier. We wish to thank Susan Kirk, Sébastien Leduc, and Marie-Ève Sigouin for technical assistance.

\section{REFERENCES}

Bates, M.R., K.W. Buck, and C.M. Brasier. 1993. Molecular relationships between Ophiostoma ulmi and the NAN and EAN races of $O$. novo-ulmi determined by restriction fragment length polymorphisms of nuclear DNA. Mycol. Res. 97 : 449-455.

Bernier, L. 1993. Conventional and molecular genetic approaches to the study of pathogenicity in Ophiostoma ulmi sensu lato. Pages 293-307 in M. Sticklen and J. Sherald (eds.), Dutch Elm Disease Research: Cellular and Molecular Approaches. Springer-Verlag, New York, NY, USA.

Bernier, L., and M. Hubbes. 1990a. Mutations in Ophiostoma ulmi induced by $N$-methyl- $N$ '-nitro- $N$-nitrosoguanidine. Can. J. Bot. 68 : 225-231.

Bernier, L, and M. Hubbes. 1990b. Meiotic analysis of induced mutations in Ophiostoma ulmi. Can. J. Bot. 68 : 232-235

Bouvet, G.F., V. Jacobi, K.V. Plourde, and L. Bernier. 2008. Stress-induced mobility of OPHIO1 and OPHIO2, DNA transposons of the Dutch elm disease fungi. Fungal Genet. Biol. 45 : 565-578.

Brasier, C.M. 1981. Laboratory investigation of Ceratocystis ulmi. Pages 76-79 in R.J. Stipes and R.J. Campana (eds.), Compendium of Elm Diseases. American Phytopathological Society Press. St. Paul, MN, USA.

Brasier, C.M. 1986a. A comparison of pathogenicity and cultural characteristics in the EAN and NAN aggressive sub-groups of Ophiostoma ulmi. Trans. Brit. Mycol. Soc. $87: 1-13$.

Brasier, C.M. 1986b. The population biology of Dutch elm disease: its principal feature and some implications for other host-pathogen systems. Adv. Plant Pathol. 5 : 55-118.

Brasier, C.M. 1987. Some genetical aspects of necrotrophy with special reference to Ophiostoma-ulmi. Pages 297-310 in P.R. Day and G.J. Jellis (eds.), Genetics and Plant Pathogenesis. Blackwell Scientific Publications, Oxford, UK.

Brasier, C.M. 1990. China and the origins of Dutch elm disease: an appraisal. Plant Pathol. 39 : 5-16.

Brasier, C.M. 1991. Ophiostoma novo-ulmi sp. nov., causative agent of current Dutch elm disease pandemics. Mycopathologia 115 : 151-161.

Brasier, C.M. 1995. Episodic selection as a force in fungal evolution with special reference to clonal speciation and hybrid introgression. Can. J. Bot. 73 : S1213-1221.

Brasier, C.M., and F. Afsharpour. 1979. The aggressive and non-aggressive strains of Ceratocystis ulmi in Iran. Eur. J. For. Pathol. 9 : 113-122.

Brasier, C.M., K.W. Buck, M. Paoletti, L. Crawford, and S.A. Kirk. 2004. Molecular analysis of evolutionary changes in populations of Ophiostoma novo-ulmi. Invest Agrar: Sist Recur For 13 : 93-103.
Brasier, C.M., S.A. Kirk, N.D. Pipe, and K.W. Buck. 1998. Rare interspecific hybrids in natural populations of the Dutch elm disease pathogens Ophiostoma ulmi and O. novo-ulmi. Mycol. Res. 102 : 45-57.

Brasier, C.M., S.A Kirk, and S. Tegli. 1995. Naturally occurring non cerato-ulmin producing mutants of Ophiostoma novo-ulmi are pathogenic but lack aerial mycelium. Mycol. Res. 99 : 436-440.

Brasier, C.M., J. Lea, and M.K. Rawlings. 1981. The aggressive and non-aggressive strains of Ceratocystis ulmi have different temperature optima for growth. Trans. Brit. Mycol. Soc. 76 : 213-218.

Brasier, C.M., and M.D. Mehrotra. 1995. Ophiostoma himalulmi sp. nov., a new species of Dutch elm disease fungus endemic to the Himalayas. Mycol. Res. 99 : 205-215.

Brasier, C.M., and J.F. Webber. 1987. Positive correlations between in vitro growth rate and pathogenesis in Ophiostoma ulmi. Plant Pathol. 36 : 462-466.

Comeau, A.M., J. Dufour, G.F. Bouvet, M. Nigg, V. Jacobi, B. Henrissat, J. Laroche, R.C. Levesque, and L. Bernier. 2015. Functional annotation of the Ophiostoma novoulmi genome: insights into the phytopathogenicity of the fungal agent of Dutch elm disease. Genome Biol. Evol. $7: 410-430$.

Dewar, K., and L. Bernier. 1995. Inheritance patterns of nonhomologous chromosomes in Ophiostoma ulmi sensu lato. Curr. Genet. 27 : 541-549.

Dewar, K., J. Bousquet, J. Dufour, and L. Bernier. 1997. A meiotically reproducible chromosome length polymorphism in the ascomycete fungus Ophiostoma ulmi (sensu lato). Mol. Gen. Genet. 255 : 38-44.

Dusabenyagasani, M., J. Dufour, and L. Bernier. 2000. Approaches for genomic mapping of the Dutch elm disease pathogens. Phytopathology 90 : S21 (Abstract).

Et-Touil, A., C.M. Brasier, and L. Bernier. 1999. Localization of a pathogenicity gene in Ophiostoma novo-ulmi and evidence that it may be introgressed from 0 . ulmi. Molec. Plant-Microbe Interac. 12 : 6-15.

Et-Touil, A., D. Rioux, F.M. Mathieu, and L. Bernier. 2005. External symptoms and histopathological changes following inoculation of elms putatively resistant to Dutch elm disease with genetically close strains of Ophiostoma. Can. J. Bot. 83 : 656-667.

Forgetta, V., G. Leveque, J. Dias, D. Grove, R. Lyons Jr., S. Genik, C. Wright, S. Singh, N. Peterson, M. Zianni, J. Kieleczawa, W. Hintz, V. Jacobi, L. Bernier, R. Levesque, and K. Dewar. 2013. Sequencing of the Dutch elm disease fungus genome using the Roche/454 GS-FLX Titanium system in a comparison of multiple genomics core facilities. J. Biomol. Tech. 24 : 39-49.

Khoshraftar, S., S. Hung, S. Khan, Y. Gong, V. Tyagi, J. Parkinson, M. Sain, A.M. Moses, and D. Christendat. 2013. Sequencing and annotation of the Ophiostoma ulmi genome. BMC Genomics 14 : 162.

Lander, E.S, P. Green, J. Abrahamson, A. Barlow, M.J. Daly, S.E. Lincoln, and L. Newburg. 1987. MAPMAKER: an interactive computer package for constructing primary genetic linkage maps of experimental and natural populations. Genomics 1 : 174-181.

Michelmore, R.W., I. Paran, and R.V. Kessell. 1991. Identification of markers linked to disease resistance genes by bulked segregant analysis: a rapid method to detect markers in specific genomic regions using segregating populations. Proc. Natl. Acad. Sci. USA 88: 9828-9832.

Orita, M., Y. Suzuki, T. Sekiya, and K. Hayashi. 1989. Rapid and sensitive detection of point mutations and DNA polymorphisms using the polymerase chain reaction. Genomics 5 : 874-879. 
Paoletti, M., K.W. Buck, and C.M. Brasier. 2006. Selective acquisition of novel mating type and vegetative incompatibility genes via interspecies gene transfer in the globally invading eukaryote Ophiostoma novo-ulmi. Mol. Ecol. 15 : 249-262.

Pipe, N.D., C.M. Brasier, and K.W. Buck. 2000. Two natural cerato-ulmin deficient mutants of Ophiostoma novo-ulmi: one has an introgressed $O$. ulmi cu gene; the other has an O. novo-ulmi $\mathrm{Cu}$ gene with a mutation in an intron splice consensus sequence. Mol. Plant Pathol. 1 : 379-382.

Pipe, N.D., K.W. Buck, and C.M. Brasier. 1995. Molecular relationships between Ophiostoma ulmi and the NAN and EAN races of 0 . novo-ulmi determined by RAPD markers. Mycol. Res. 99 : 653-658.

Scala, F., F. Bertelli, L. Coppola, G. Del Sorbo, S. Tegli, and A. Scala. 1997. Comparative determination of cerato-ulmin on cell surface and in mycelial extracts of pathogenic and non-pathogenic Ophiostoma species. Mycol. Res. 101 : 829-834.

Takai, S. 1980. Relationship of the production of the toxin, cerato-ulmin, to synnemata formation, pathogenicity, mycelial habit, and growth of Ceratocystis ulmi isolates. Can. J. Bot. $58: 658-662$.

Takai, S., and W.C. Richards. 1978. Cerato-ulmin, a wilting toxin of Ceratocystis ulmi: isolation and some properties of cerato-ulmin from the culture of $C$. ulmi. Phytopathol. Z. 91 : 129-146.

Temple, B, P.A. Horgen, L. Bernier, and W.E. Hintz. 1997. Cerato-ulmin, a hydrophobin secreted by the causal agents of Dutch elm disease, is a parasitic fitness factor. Fungal Genet. Biol. 22 : 39-53.

Zolan, M., and P. Pukkila. 1986. Inheritance of DNA methylation in Coprinus cinereus. Mol. Cell. Biol. 6 : 195200. 